\title{
Assessment of indoor SPM in households of sub-urban areas of District Jammu (J\&K)
}

\author{
Choudhary Sonika and Rampal Raj Kumar 网
}

Received: 21.04.2018
Accepted: 14.07.2018

\begin{abstract}
In present study attempt has been made to study Indoor SPM in households of sub-urban areas of District Jammu (J\&K). Average indoor SPM at all the polluted sites and sub-sites was observed to be above permissible limit and at reference site it was observed to be below permissible limit
\end{abstract}

Key words: Suspended particulate matter, polyaeromatic hydrocarbons (PAH),

\section{Introduction}

Environmental pollution, an incurable disease, is encircling the entire earth these days. It acts as a sluggish health eater and is responsible for premature deaths all over the world. The top five leading countries with good air quality are Switzerland, France, Denmark, Malta and Sweden and the bottom five are Nepal, India, Democratic Republic of Congo, Bangladesh and Burundi (The Hindu, 2018. In India, the top six most polluted cities with highest pollution index are Ghaziabad (97.67), Faridabad (95.89), Kanpur (94.69), Noida (92.28), Varanasi (91.93) and Delhi (91.79) (www.numbeo.com). Biomass being renewable source includes agricultural crops, trees, wood residues, grasses, municipal residues and other plant derived material like bio-energy etc (Christopher et. al., 2009) and its use is mainly responsible for household pollution. Air quality of a country determines the environmental conditions prevailing in that country (Singh, 2016). Mainly, air pollutants are classified into two types i.e. outdoor and indoor air pollutants which are associated with health impacts (Ghosh and Parida, 2015). In rural areas, mostly people use solid fuels, biomass (wood, dung, agricultural residues). The incomplete combustion of these fuels releases SPM, CO, polyaeromatic hydrocarbons, polyorganic matter, formaldehyde etc which can cause serious health

\section{Author's Address}

Deartment of Environmental Science, University of Jammu, Jammu (J\&K)

E-mail.: rajkrampal@gmail.com effects (Kankaria et. al., 2014). People which uses $24 \mathrm{hr}$ solid fuels for cooking purpose may get exposed to particulate matter as high as 10,000 $\mathrm{ug} / \mathrm{m}^{3}$ whereas $\mathrm{WHO}$ recommends that $\mathrm{PM}_{2.5}$ and $\mathrm{PM}_{10}$ exposure limits should not go beyond 25 and $50 \mathrm{ug} / \mathrm{m}^{3}$ respectively (Gall et. al., 2013).

The various other important building related illnesses are Sick Building Syndrome, Building Related Illness and Multiple Chemical Sensitivity. Sick Building Syndrome (SBS) combines a series of acute complaints like irritation to eyes, nose and throat, headache, stuffy nose, mental fatigue and skin irritation. The symptoms disappear as soon as they leave the building. Building Related Illness (BRI) refer to illness with a known causative agent like drain pans for filters, other wet surfaces, water damaged building material etc. Around world, in 2012 air pollution was responsible for 1 out of every 8 deaths globally or 7 million deaths out of which 600,000 were children under five year of age (Mascarenhas, 2017). Among most affected ones a large fraction was from women due to their more engagement in cooking and other domestic works and children because they spend most of their time indoor. Among children also the most affected ones are girls than boys. In present study, attempt has been made to determine indoor air quality with the respect to SPM in houses around brick kiln areas at seven sub-urban sites of District Jammu. 


\section{Material and methods}

The study area lies in District Jammu (J\& K). The study area was divided into Seven sites i.e. One Reference site-R (Dumi) and six polluted sites i.e. Polluted site- $\mathrm{P}_{1}$ (Baba Talab), Polluted site- $\mathrm{P}_{2}$ (Marjali), Polluted site- $\mathrm{P}_{3}$ (Suka Pakyian), Polluted site- $\mathrm{P}_{4}$ (Main Mishriwala), Polluted site- $\mathrm{P}_{5}$ (Jhiri road Mishriwala) and Polluted site- $\mathrm{P}_{6}$ (Mishriwala). At each site three households were selected to carry out indoor air sampling. The sampling of SPM was done at each sub-site was done thrice i.e. two during brick kiln non-operational season (July to Feb 2017) and one during brick kiln operational season (March to June 2018). The sampling was done for 8 hours from 7 am to 3pm using Ecotech Handy Air Sampler IAS 019 and Mettler-Toledo MS105DU balance by CPCB recommended Gravimetric method (APHA, 1987).

SPM was calculated in $\mu \mathrm{g} / \mathrm{m}^{3}$ using formula.

$$
\operatorname{SPM}\left(\mu \mathrm{g} / \mathrm{m}^{3}\right)=\frac{\left(W_{2}-W_{1}\right) \times 10^{3}}{V}
$$

Where, $\mathrm{W}_{2}=$ Final weight of filter paper

$\mathrm{W}_{1}=$ Initial weight of filter paper

$$
V=\frac{\left(F_{1}+F_{2}\right) \times T}{2}
$$

Where, $\mathrm{F}_{1}=$ Initial flow rate of air in $1 \mathrm{pm}$ $\mathrm{F}_{2}=$ Final flow rate of air in $1 \mathrm{pm}$

\section{Results and Discussion}

The analysis of data of indoor SPM revealed that average values exhibited comparatively higher in the kitchens of both reference and polluted sites i.e. $114 \pm 9 \mu \mathrm{g} / \mathrm{m}^{3}$ and $441 \pm 89 \mu \mathrm{g} / \mathrm{m}^{3}$ respectively as compared with that of bedrooms and drawing room. On comparative basis the average indoor SPM exhibited higher values at kitchen of polluted sites as compared with that of reference site. The higher values of indoor SPM in kitchens of polluted sites might be due to the presence of brick kilns, vehicular exhaust whereas comparatively less indoor SPM was observed in kitchen at reference site because the site was free from brick kiln smoke and vehicular exhaust. The result was found to be similar with the findings of Rampal and Manhas 2004 who also reported that kitchen comparatively exhibited higher values of indoor SPM irrespective of its location than bedroom and drawing room in residential area of Bishnah Town. The bedrooms and drawing rooms of polluted sites exhibited an average higher value of $356 \pm 67 \mu \mathrm{g} / \mathrm{m}^{3}$ and $356 \pm 89$ $\mu \mathrm{g} / \mathrm{m}^{3}$ respectively whereas bedrooms and drawing rooms of reference site showed an average lower values of $99 \pm 7 \mu \mathrm{g} / \mathrm{m}^{3}$ and $59 \pm 34 \mu \mathrm{g} / \mathrm{m}^{3}$ (Table:VIII). The bedrooms and drawing rooms of the polluted sites showed more indoor SPM as compared to bedrooms and drawing rooms of reference sites because households at polluted sites were located adjoining brick kilns area. On the other hand Singh 2009 while assessing indoor air quality in the households adjoining the Industrial Estate-Gangyal, Jammu reported more indoor SPM in living rooms as compared to that of kitchens and bedrooms. The critical analysis of the indoor SPM data revealed that Kitchens at Site- $\mathrm{P}_{3}$ exhibited maximum average indoor SPM of $538 \pm 488 \mu \mathrm{g} / \mathrm{m}^{3}$ whereas minimum average value of $281 \pm 126 \mu \mathrm{g} / \mathrm{m}^{3}$ (Table:VIII) of indoor SPM was observed in the kitchens at Site- $\mathrm{P}_{6}$ because of this site at the upward wind side of brick kilns. At Polluted Site- $\mathrm{P}_{3}$ the highest value of $1224 \mu \mathrm{g} / \mathrm{m}^{3}$ of indoor SPM was observed during brick kiln-operating season in kitchen of household $\mathrm{P}_{3} \mathrm{H}_{3}$ due to outside unattached kitchen without exhaust fan, thereby more influenced by outdoor environment due to dust raised from kacha road, soil excavation and raw brick making practices at this site whereas minimum of $132 \mu \mathrm{g} / \mathrm{m}^{3}$ of indoor SPM was observed in the kitchen of household $\mathrm{P}_{3} \mathrm{H}_{2}$ during non-operating brick kiln season moreover the house was properly cleaned and mode of cooking was heater. At Polluted Site- $\mathrm{P}_{6}$ minimum value of 140 $\mu \mathrm{g} / \mathrm{m}^{3}$ was observed during brick kiln off season at kitchen of household $\mathrm{P}_{6} \mathrm{H}_{2}$ because the kitchen was inside, properly cleaned, provided with exhaust fan and LPG was the main mode of cooking whereas highest value of $446 \mu \mathrm{g} / \mathrm{m}^{3}$ of indoor SPM was observed at kitchen of household $\mathrm{P}_{6} \mathrm{H}_{3}$ during brick kiln-operating season because the kitchen was without exhaust fan though the mode of cooking was LPG (Table: VII).

The further critical analysis of the data of indoor SPM of bedrooms at polluted sites revealed that bedrooms of polluted Site- $\mathrm{P}_{1}$ exhibited maximum average indoor SPM of $437 \pm 12 \mu \mathrm{g} / \mathrm{m}^{3}$ (Table: VIII) with a range of 420-446 whereas minimum average indoor SPM was observed in bedrooms at Site- $\mathrm{P}_{4}$ 
Table-I. Indoor SPM level at Reference Site (R).

\begin{tabular}{|l|l|l|l|c|}
\hline \multirow{2}{*}{ House no. } & \multicolumn{4}{|c|}{ Indoor SPM $\left(\boldsymbol{\mu g} / \mathbf{m}^{\mathbf{3}}\right)$ in } \\
\cline { 2 - 5 } & Kitchen & Bedroom & Drawing room & Household \\
\hline House-1. $\left(\mathrm{RH}_{1}\right)$ & 104 & 104 & 83 & $97 \pm 10(83-104)$ \\
\hline House-2. $\left(\mathrm{RH}_{2}\right)$ & 125 & 104 & 83 & $104 \pm 17(125-83)$ \\
\hline House-3. $\left(\mathrm{RH}_{3}\right)$ & 114 & 90 & 10 & $71 \pm 44(10-114)$ \\
\hline Average & $114 \pm 9(104-125)$ & $99 \pm 7(90-104)$ & $59 \pm 34(10-83)$ & $91 \pm 14(71-104)$ \\
\hline
\end{tabular}

Table-II. Indoor SPM level at Polluted Site-1 $\left(\mathbf{P}_{1}\right)$.

\begin{tabular}{|c|c|c|c|c|}
\hline \multirow[b]{2}{*}{ House no. } & \multicolumn{3}{|c|}{ Indoor SPM $\left(\mu \mathrm{g} / \mathrm{m}^{3}\right)$ in } & \multirow[b]{2}{*}{ Household } \\
\hline & Kitchen & Bedroom & Drawing room & \\
\hline House -1. $\left(\mathrm{P}_{1} \mathrm{H}_{1}\right)$ & 251 & 446 & 501 & $399 \pm 107(251-501)$ \\
\hline House-2. $\left(\mathrm{P}_{1} \mathrm{H}_{2}\right)$ & 446 & 446 & 149 & $347 \pm 140(149-446)$ \\
\hline House-3. $\left(\mathrm{P}_{1} \mathrm{H}_{3}\right)$ & 560 & 420 & 375 & $452 \pm 79(375-560)$ \\
\hline Average & $419 \pm 128(251-560)$ & $437 \pm 12(420-446)$ & $342 \pm 146(149-501)$ & $399 \pm 43(347-452)$ \\
\hline
\end{tabular}

Table-III. Indoor SPM level at Polluted Site-2( $\left.\mathbf{P}_{2}\right)$.

\begin{tabular}{|c|c|c|c|c|}
\hline \multirow[b]{2}{*}{ House no. } & \multicolumn{3}{|c|}{ Indoor SPM $\left(\mu \mathrm{g} / \mathrm{m}^{3}\right)$ in } & \multirow[b]{2}{*}{ Household } \\
\hline & Kitchen & Bedroom & Drawing room & \\
\hline House -1. $\left(\mathrm{P}_{2} \mathrm{H}_{1}\right)$ & 257 & 250 & 264 & $306 \pm 6(250-264)$ \\
\hline House-2. $\left(\mathrm{P}_{2} \mathrm{H}_{2}\right)$ & 386 & 396 & 257 & $346 \pm 63(257-386)$ \\
\hline House-3. $\left(\mathrm{P}_{2} \mathrm{H}_{3}\right)$ & 952 & 408 & 408 & $589 \pm 256(408-952)$ \\
\hline Average & $532 \pm 302(257-952)$ & $351 \pm 72(250-408)$ & $310 \pm 70(257-408)$ & $398 \pm 140(306-589)$ \\
\hline
\end{tabular}

Table-IV. Indoor SPM level at Polluted Site-3 $\left(\mathbf{P}_{\mathbf{3}}\right)$.

\begin{tabular}{|l|l|l|l|l|}
\hline \multirow{2}{*}{ House no. } & \multicolumn{3}{|c|}{ Indoor SPM $\left(\boldsymbol{\mu g} / \mathbf{m}^{3}\right)$ in } \\
\cline { 2 - 5 } & Kitchen & Bedroom & Drawing room & Household \\
\hline House -1. $\left(\mathrm{P}_{3} \mathrm{H}_{1}\right)$ & 257 & 396 & 264 & $306 \pm 64(257-396)$ \\
\hline House-2. $\left(\mathrm{P}_{3} \mathrm{H}_{2}\right)$ & 132 & 264 & 264 & $220 \pm 62(132-264)$ \\
\hline House-3. $\left(\mathrm{P}_{3} \mathrm{H}_{3}\right)$ & 1224 & 408 & 560 & $731 \pm 354(408-1224)$ \\
\hline Average & $538 \pm 48(8132-1224)$ & $356 \pm 65(264-408)$ & $363 \pm 140(264-560)$ & $419 \pm 223(220-731)$ \\
\hline
\end{tabular}

Table-V. Indoor SPM level at Polluted Site-4 $\left(\mathbf{P}_{4}\right)$.

\begin{tabular}{|c|c|c|c|c|}
\hline \multirow[b]{2}{*}{ House no. } & \multicolumn{3}{|c|}{ Indoor SPM $\left(\mu \mathrm{g} / \mathrm{m}^{3}\right)$ in } & \multirow[b]{2}{*}{ Household } \\
\hline & Kitchen & Bedroom & Drawing room & \\
\hline House - $1 .\left(\mathrm{P}_{4} \mathrm{H}_{1}\right)$ & 194 & 198 & 132 & $175 \pm 30(132-198)$ \\
\hline House-2. $\left(\mathrm{P}_{4} \mathrm{H}_{2}\right)$ & 264 & 132 & 264 & $220 \pm 62(132-264)$ \\
\hline House-3. $\left(\mathrm{P}_{4} \mathrm{H}_{3}\right)$ & 721 & 375 & 396 & $497 \pm 158(721-396)$ \\
\hline Average & $393 \pm 234(194-721)$ & $235 \pm 103(132-375)$ & $264 \pm 108(132-396)$ & $297 \pm 143(175-497)$ \\
\hline
\end{tabular}


Table-VI. Indoor SPM level at Polluted Site-5 $\left(\mathbf{P}_{5}\right)$.

\begin{tabular}{|c|c|c|c|c|}
\hline \multirow[b]{2}{*}{ House no. } & \multicolumn{3}{|c|}{ Indoor SPM $\left(\mu \mathrm{g} / \mathrm{m}^{3}\right)$ in } & \multirow[b]{2}{*}{ Household } \\
\hline & Kitchen & Bedroom & Drawing room & \\
\hline House -1. $\left(\mathrm{P}_{5} \mathrm{H}_{1}\right)$ & 544 & 140 & 680 & $455 \pm 229(140-680)$ \\
\hline House-2. $\left(\mathrm{P}_{5} \mathrm{H}_{2}\right)$ & 408 & 257 & 420 & $362 \pm 7(257-420)$ \\
\hline House-3. $\left(\mathrm{P}_{5} \mathrm{H}_{3}\right)$ & 501 & 595 & 529 & $542 \pm 3(501-595)$ \\
\hline Average & $484 \pm 5(408-544)$ & $331 \pm 19(140-595)$ & $543 \pm 10(420-680)$ & $45373(362-542)$ \\
\hline
\end{tabular}

Table-VII. Indoor SPM level at Polluted Site-6 $\left(\mathbf{P}_{6}\right)$.

\begin{tabular}{|l|l|l|l|l|}
\hline \multirow{2}{*}{ House no. } & \multicolumn{3}{|c|}{ Indoor SPM $\left(\boldsymbol{\mu g} / \mathbf{m}^{3}\right)$ in } & Household \\
\cline { 2 - 5 } & Kitchen & Bedroom & 272 & $336 \pm 10(257-480)$ \\
\hline House -1. $\left(\mathrm{P}_{6} \mathrm{H}_{1}\right)$ & 257 & 480 & 264 & $267 \pm 10(140-396)$ \\
\hline House-2. $\left(\mathrm{P}_{6} \mathrm{H}_{2}\right)$ & 140 & 396 & 408 & $421 \pm 1(408-446)$ \\
\hline House-3. $\left(\mathrm{P}_{6} \mathrm{H}_{3}\right)$ & 446 & 408 & $315 \pm 6(264-408)$ & $341 \pm 6(267-421)$ \\
\hline Average & $281 \pm 126(140-446)$ & $428 \pm 37(396-480)$ & & \\
\hline
\end{tabular}

Table-VIII. Indoor SPM level at Reference and Polluted Sites of study area.

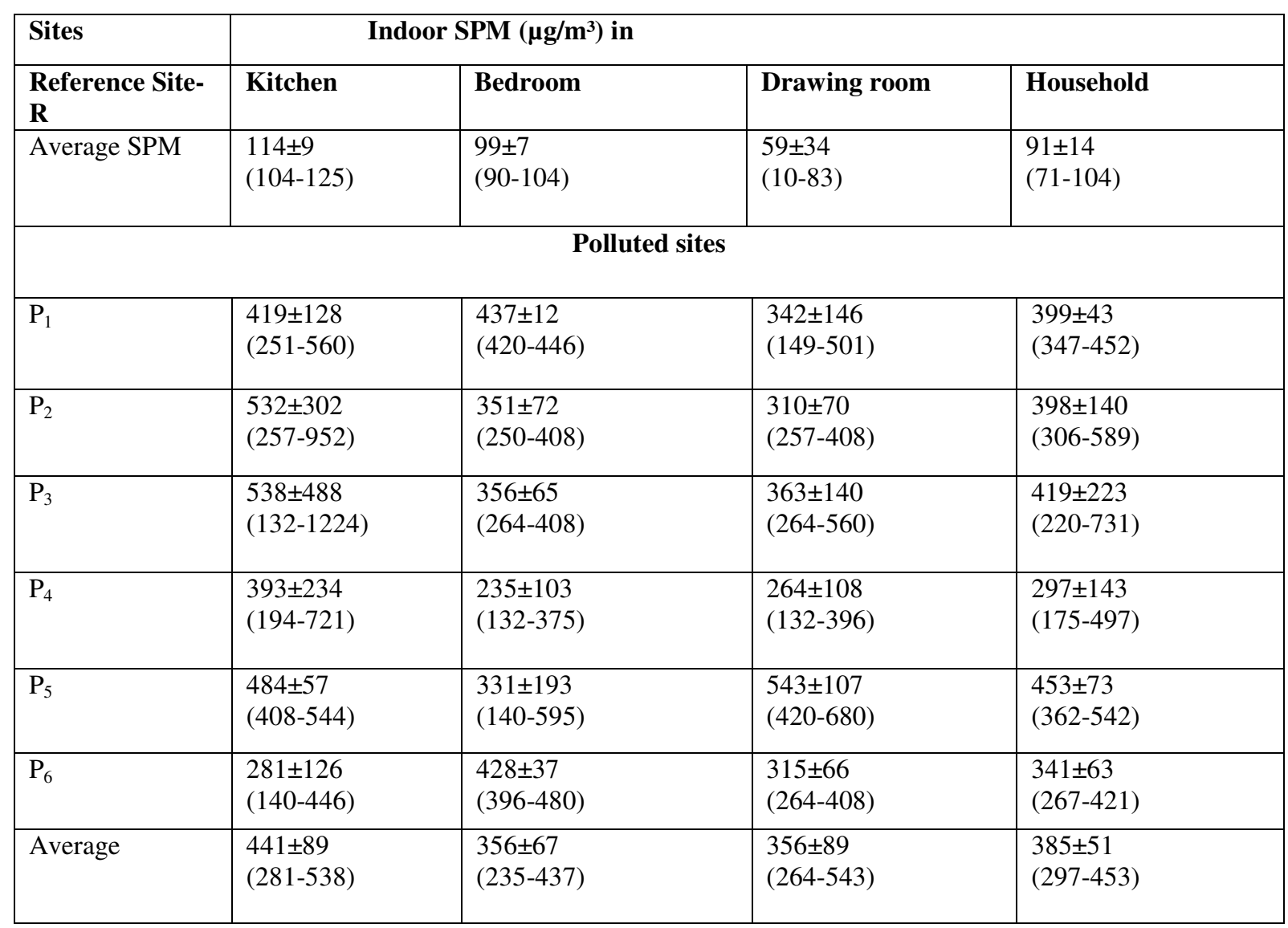


Assessment of indoor SPM in households of sub-urban areas

Table-IX Indoor air quality in households at polluted sites during brick kiln on and off season

\begin{tabular}{|c|c|c|}
\hline \multirow{2}{*}{ Polluted sites } & \multicolumn{2}{|c|}{ SPM $\left(\boldsymbol{\mu g} / \mathbf{m}^{\mathbf{3}}\right)$} \\
\cline { 2 - 3 } & OFF & ON \\
\hline $\mathrm{P}_{1}$ & 347 & 552 \\
\hline $\mathrm{P}_{2}$ & 306 & 589 \\
\hline $\mathrm{P}_{3}$ & 220 & 731 \\
\hline $\mathrm{P}_{4}$ & 175 & 497 \\
\hline $\mathrm{P}_{5}$ & 362 & 542 \\
\hline $\mathrm{P}_{6}$ & 297 & 453 \\
\hline Average & $285 \pm 67$ & $544 \pm 97$ \\
& $(175-362)$ & $(542-731)$ \\
\hline
\end{tabular}

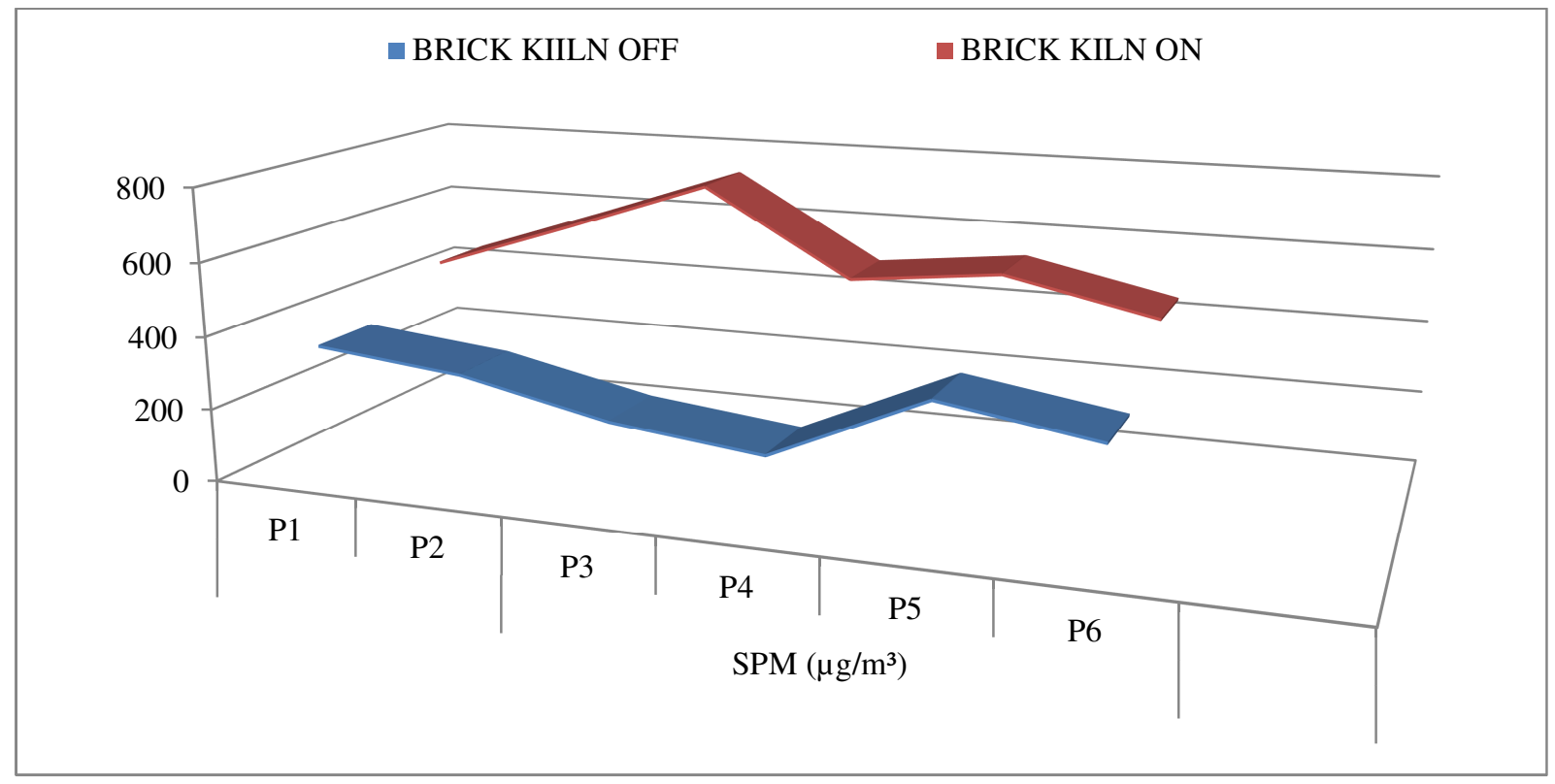

i.e. $235 \pm 103 \mu \mathrm{g} / \mathrm{m}^{3}$ with a range of $132-375 \mu \mathrm{g} / \mathrm{m}^{3}$. The highest indoor SPM in bedrooms of Site- $\mathrm{P}_{1}$ was due to lack of cleanliness beside this, the site was surrounded by about eight brick kilns at various distances whereas the lowest indoor SPM was observed at Site- $\mathrm{P}_{4}$ bedrooms due to presence of only two brick kilns at about $250-300 \mathrm{~m}$ distance and moreover site was present in the shadow of the brick kiln plume. At Polluted Site- $\mathrm{P}_{1}$ maximum indoor SPM of $446 \mu \mathrm{g} / \mathrm{m}^{3}$ (Table: II) was observed in bedroom of Household $\mathrm{P}_{1} \mathrm{H}_{1}$ and $\mathrm{P}_{1} \mathrm{H}_{2}$ due to attached kitchen adjacent to bedrooms, moreover the bedrooms were provided with windows, so the outdoor sources might be enhancing indoor SPM whereas minimum indoor SPM of $420 \mu \mathrm{g} / \mathrm{m}^{3}$ was observed in bedroom of household $\mathrm{P}_{1} \mathrm{H}_{3}$ due to unattached kitchen and bedroom was not provided with proper windows. At Site- $\mathrm{P}_{4}$ of household $\mathrm{P}_{4} \mathrm{H}_{3}$ bedrooms the maximum indoor SPM of $375 \mu \mathrm{g} / \mathrm{m}^{3}$ was observed during brick kiln operating season moreover cleanliness was not proper, whitewash of the bedroom was not done for the last many years whereas minimum indoor SPM of $132 \mu \mathrm{g} / \mathrm{m}^{3}$ was observed at bedroom of household $\mathrm{P}_{4} \mathrm{H}_{2}$ due to non- 


\section{Choudhary and Rampal}

operational phase of brick kiln moreover bedroom was away from the kitchen (Table: V). The compilation of the data of indoor SPM of drawing rooms revealed that the maximum average indoor SPM was observed at Site- $\mathrm{P}_{5}$ i.e. $543 \pm 107 \mu \mathrm{g} / \mathrm{m}^{3}$ (Table: VIII) whereas minimum average was observed at Site- $\mathrm{P}_{4}$ i.e. $264 \pm 108 \mu \mathrm{g} / \mathrm{m}^{3}$ due to location of site on the downward side of brick kilns and location of Site- $\mathrm{P}_{4}$ in the shadow zone of the brick kiln plume respectively. At Site- $\mathrm{P}_{5}$ maximum value of indoor SPM $680 \mu \mathrm{g} / \mathrm{m}^{3}$ (Table-VI) was observed in drawing room at Household $\mathrm{P}_{5} \mathrm{H}_{1}$ due to its location toward roadside, proper windows and more exposure towards vehicular exhaust, brick kiln smoke etc whereas minimum value of 420 $\mu \mathrm{g} / \mathrm{m}^{3}$ was observed in drawing room of household $\mathrm{P}_{5} \mathrm{H}_{2}$ during non-operational brick kiln season moreover the drawing room was inside, away from kitchen. At Site- $\mathrm{P}_{4}$, maximum indoor SPM of 396 $\mu \mathrm{g} / \mathrm{m}^{3}$ was observed in drawing room at Household $\mathrm{P}_{4} \mathrm{H}_{3}$ during brick kiln operational season as the drawing room was properly ventilated with windows and in spite of its location in the shadow zone it was close to the road and affected by dust from vehicular exhaust while minimum indoor SPM of $132 \mu \mathrm{g} / \mathrm{m}^{3}$ (Table-V) was observed in the drawing room at household $\mathrm{P}_{4} \mathrm{H}_{1}$ as the sampling was done during non-operation brick kiln season i.e. in winter when people use to keep their windows, door closed so less influenced by kitchen SPM. Average indoor SPM at all the polluted sites and sub-sites was observed to be above permissible limit $\left(100 \mu \mathrm{g} / \mathrm{m}^{3}\right)$. Similar kinds of results were observed by Kulshreshtha et. al., 2008 and Waseem et. al., 2013 while assessing Indoor Air Quality at Nizamuddin and Aligarh respectively observed SPM beyond permissible limit whereas at reference site average indoor SPM was below permissible limit $\left(100 \mu \mathrm{g} / \mathrm{m}^{3}\right)$ in both bedroom and drawing room but above permissible limit in kitchen. The compilation of data of all the households revealed that maximum SPM values i.e. $544 \pm 97 \mu \mathrm{g} / \mathrm{m}^{3}$ was observed during brick kiln operational season while minimum i.e. $285 \pm 67 \mu \mathrm{g} / \mathrm{m}$ was observed during brick kiln off season (Table-IX) (Fig: 1). The average SPM at the reference site was $91 \pm 14 \mu \mathrm{g} / \mathrm{m}^{3}$, whereas at the polluted sites the average SPM was observed to be $385 \pm 15 \mu \mathrm{g} / \mathrm{m}^{3}$ (Table-VIII). From the above discussion it can be concluded that SPM was observed to be the main culprit of indoor air pollution in the households adjoining brick kiln area.

\section{References}

APHA 1987. Methods of air sampling and analysis $\left(2^{\text {nd }}\right.$ edition). American Public Health Association, Washington DC, USA, pp-984.

Christopher, S., Robert, C. Abt. And Yun, Wu. 2009. Forest biomass supply in the southeastern united stateimplications for industrial round wood and bioenergy production. Journal of Forest, 107:69-77.

Gall, E. T., Carter, E. M., Earnest, C. M. and Stephens, B. 2013. Indoor air pollution in developing countries: Research and implementation needs for improvement in global public health. Journal of Public Health, 103(4):67-72.

Ghosh, D. and Parida, P. 2015. Air pollution and India: Current scenario. International Journal of Current Research, 7(11):22194-22196.

Kankaria, A., Nongkyrih B. and Gupta, S. K. 2014. Indoor air pollution in India: Implications on health and its control. Indian Journal of Community Medicine, 39(4):203-207.

Kulshreshtha, P., Khare, M. and Seetharaman, P. 2008. Indoor air quality assessment in and around urban slums of Delhi City, India. International Journal of Indoor Environment and Health, 18(6):488-498.

Mascarenhas, A. 2017. At, 2.5 million, India tops list of pollution-linkes deaths:Study. The Indian Express, October 20, 2017.

Rampal, R. K. and Manhas, K. 2004. Assessment of indoor SPM level in sub urban residential area of Jammu (J\&K), India. Indian Journal of Environment and Ecoplan, 8(1):91-96.

Singh, A. 2016. A study of ambient air quality of Yamuna Nagar city in Haryana. Biological Forum, 8(2):392-396.

Singh, C. 2009. Assessment of indoor air quality in the households adjoining the Industrial Estate-Gangyal, Jammu. M.phil dissertation submitted to university of Jammu.

The Hindu 2018 Environmental performance index 2018, 24 January 2018, New Delhi. http://www.thehindu.com.

Waseem, S., Ashraf, A., Khanam, S. and Ahmad, A. 2013. Effects of indoor air pollution on human health: A microlevel study of Aligarh city-India. Merit Research Journal of Education and Review, 1(6):139-146.

www.numbeo.com.http:/www.numbeo.com/pollution/country result jsp?country=india. 